\begin{abstract}
Alberta
\section{New Chairman Appointed}

Dr. James Beck Jr. has stepped down as department chairman after serving in that capacity for five years plus almost another two years as acting Chair. Jim commenced a year-long administrative leave as of June 1 , 1989 of which six months will be spent in Berkeley, California with the Department of Forestry and Resource Management, University of California; and six months with Weldwood of Canada Ltd., at Hinton, working on integrating wildlife and other concerns into a truly comprehensive forest management scheme. Jim will return to Edmonton in the fall of 1990 .
\end{abstract}

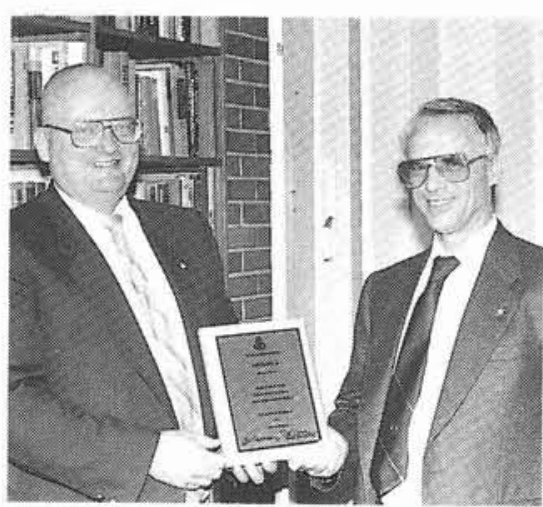

Dr. Peter Murphy, Assistant Dean (right), extended thanks to Dr. Jim Beck for his many contributions to the Forestry Program as Chairman.

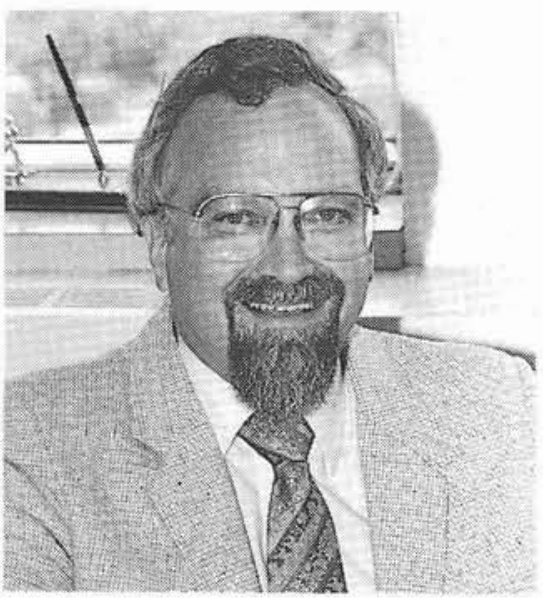

Dr. Bruce Dancik, newly appointed Chairman for the Department of Forest Science.

Dr. Bruce Dancik, has recently been appointed chairman. Bruce is no stranger to the department and teaches dendrology dendrology and tree imporvement. $\mathrm{He}$ is also Assistant Editor-in-Chief for the NRC Research Journals and is editor of the Canadian Journal of Forest Research. Besides this Bruce was recently appointed to Chair the Expert Review Panel on Forest Management in Alberta, which is reviewing questions, concerns and issues raised by the public over recent northern Alberta forestry developments. A busy man!

\section{Wajax Fire Management Technical Report Competition}

Mr. Ken Greenway, a fourth-year student in the Department of Forest Science, is the first prize winner of the 1989 Wajax Fire Management Technical Report Competition. $\mathrm{Mr}$. Greenway's winning submission is titled "The use of superabsorbents as a firebreak in forest community interfaces." In his manuscript, he discusses the feasibility of using a starch grafted polyacrylonitrile copolymer, a superabsorbant compound, to alter the moisture status of fine fuels. This original idea was developed in an attempt to indemnify high value-at-risk structures from wildfires while maintaining some degree of "naturalness."

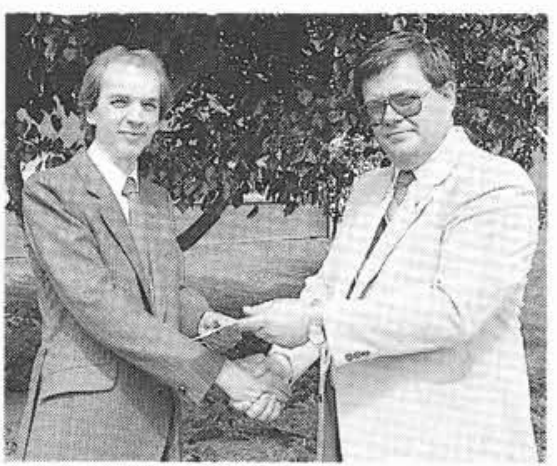

Mr. Ken Greenway receiving his $\$ 1000$ cheque from Mr. Bob Reid, Vice-President (Alberta), Wajax Industries Limited.

Ken Greenway was born (1963) and raised in Jhansi, India. He graduated from the Woodstock High School in Mussoorie, U.P., India in 1978. Ken returned to live in Calgary in 1982. From 1983 to 1985 , he attended the University of Calgary, majoring in biology. $\mathrm{He}$ transferred to the forest science program in the Faculty of Agriculture and Forestry at the University of Alberta in January of 1987. His primary interests are forest ecology and silviculture.

Ken received the Herbert and Jeanette Hall Scholarship in 1987 and a Northlands Scholarship in 1988, for his outstanding academic performance while at the University of Alberta. Currently, he is a NSERC undergraduate student research award recipient. and is actively pursuing his research interests under the guidance of Dr. Vic Lieffers.

\section{New Graduates}

The department extends congratulations to the following graduate students who received their degrees at the spring convocation

- Kevin Brown. Effects of atmospheric $\mathrm{CO}^{2}$ enrichment and nitrogen availability on growth, water use, and nutrition of seedlings of boreal trees (Ph.D.)

- Glen Hvenegaard. The economic values of bird watching at Point Pelee National Park, Ontario (M.Sc.)

- Paul Jefferson. Discriminant functions in tree breeding (Ph.D.)

- Lyn Konowalyk. Expression of root growth potential of white spruce seedlings: soil temperature and moisture effects (M.Sc.)

- Nora Kopjar. Alternatives for bison management in Banff National Park (M.Sc.)

- Roland R. Maw. Visitor attitudes, perceptions, and knowledge concerning bears and bear management practices, Waterton Lakes National Park, Canada (Ph.D.)

- Michael S. Quinn. Factors regulating the breeding population, reproductive success and mating system of the House wren (Troglodytes aedon) at Beaverhill Lake, Alberta (M.Sc.)

- Chang Yi Xie. Mating system and genetic structure of Thuja orientalis (Ph.D.)

\section{Lakehead}

\section{Student Awards}

The CIF silver rings were awarded to 42 students of our fourth year graduating class. Dean Hample, received the Northwestern Section CIF Leadership Award from Madeline Maley, the Section Chairman. Other awards were presented to forestry students at the Lakehead University Convocation, held on Saturday, 27 May. These included Dean Braun's Medal to John Andrew McLaughlin of the BScF program and Gerald Allen Regier of the Diploma in Forest Technology program. John McLaughlin also received the 
Governor-General Silver Medal for being the highest ranking student in the Honour Bachelor's degrees. Edward Henry Hoffman earned the Canadian Institute of Forestry Gold Medal for his all-round performance in sports, scholarship and citizenship. Daren John Tegel's academic performance and professionalism won him the Ontario Professional Forester's Association Prize.

\section{Forestry Symposium}

In March, the forestry students organized the 21st Annual Lakehead University Forestry Association Forestry Symposium. This year's topic was "Environmental Assessment - Its Role in Forest Management," The speakers, moderated by the Director of the School of Forestry, Dr. J. Naysmith, included: Mr. W. Green of the Ministry of the Environment; Mr. M. Jeffery, Q. C., Chairman of the Environmental Assessment Board; Mr. G. Rodgers, Ontario Ministry of Natural Resources; Mr. D. Huff, Director of Conservation, Federation of Ontario Naturalists; Ms. M. Rauter, Ontario Forestry Industries Association; and Mr. W. Brown, General Manager, Algonquin Forestry Authority. The topic was particularly pertinent, as the Environmental Assessment Hearings on Forestry started in Thunder Bay in the spring of 1988 , and may still be in progress by the spring of 1991 . Until that time, the next-todefinitive answer of the role of environmental assessment in forest management will not be answered.

Copies of the proceedings are available from the School of Forestry, Lakehead University, Tunder Bay, Ontario, P7B 5E1. Financial support for the symposium was provided by Boise Cascade Canada, Canadian Pacific Forest Products, and Lakehead University Student Union.

\section{Faculty Activity}

For the second year, Dr. H. Cumming served as a member of a three-man committee that reviewed the past five-year performance of forest companies with Ontario Forest Management Agreements. The committee is selected by the Ministry to assess company performance. This was the first committee composed of people from outside the OMNR but formerly employed by the OMNR. Dr. Cumming found that the field inspections by ground and helicopter, and the discussions with Ministry and company staff, were an excellent way to keep abreast of forestry activities within the province. Results of the 1987 survey are published under the title of "Forest Management Agreements Third Five-Year Review 1982-1987." Copies are available from the Ontario Ministry of Natural Resources, Public Information Centre, Room 1460, Whitney Block, 99 Wellesley Street West, Toronto, Ontario, M7A 1W3. Results of the 1988-89 work should be out soon.

Dr. Emil David, professor in forest harvesting, is going on sabbatical leave this year. R. J. Day and Dr. Farmer are both returning to regular teaching work after spending parts of their sabbaticals in Australia and Victoria. B. C., respectively

Dr. Reino Pulkki presented a paper entitled ' Wood quality in modelling stand investment and harvesting decisions", at the Forest Modelling Symposium held in Saskatoon in March. Later in March, he gave another paper, "Harvest systems and wood qualityeffects from stump to final product," at the CPPA Woodlands Section Annual Meeting in Montreal.

During the latter part of 1988 , Dr. Esko Mikkonen, Department of Logging and Utilization of Forestry Products, University of Helsinki, lectured on forest management in Finland. During his three weeks in Canada, he was able to give and exchange ideas on harvesting and operations research.

Dr. T. Hazenberg recently returned from a fact-finding mission to the Forestry Department of Makerere University in Kampala, Uganda. The country is just emerging from a terrible 15 -year civil war. His mission was to see what, if anything, Canada can do to help forestry education in Uganda. He suggested that aid be in various forms: support for equipment; money for buying books and subscriptions to professional and technical magazines; and above all, institutional linkages between a forestry department at a Canadian university and that of Makerere University. The European Economic Community already supports several faculties at Makerere as does USIAID, but so far no support for the forestry department has been promised. A US $\$ 31$ million World Bank loan for the forest sector of Uganda excludes professional forestry education, but it does support a two-year educational programme at the technical level. At the moment, the Forestry Department at MU has about 140 students and a faculty complement of eight, which will be permitted to expand to 15 over the next four years. While Professor Hazenberg was at MU, the faculty went on strike for higher salaries; their current salaries average US\$ $\$ 6$ per month, about enough to feed an average family for about a week. Help for forestry education is desperately needed. Financial support for the mission came from the Association of Universities and Colleges of Canada, which is essentially Canadian International Development Agency money

\section{New Chair in Forest Management and Policy}

The Chair, established at the School of Forestry with $\$ 1$ million from the Northern Development Fund of the Government of Ontario, has a mandate to develop and carry out a 5-year research plan that meets key needs of the forestry community in Ontario. Dr. Peter Duinker, who obtained his PhD in forestry at the University of New Brunswick in 1986 and then served as a research scholar in forest policy at the International Institute for Applied Systems Analysis in Austria, was appointed to the Chair in September,
1988. Dr. Duinker's main activities during his first year in the Chair have included teaching forest policy to senior forestry undergraduates, developing the research plan, and establishing a research team. Research topics to be pursued include: (a) forest land tenure, (b) sustainable community development based on forestry, (c) resolution of forest-use and environmental conflicts via mediation, (d) forestry-wildlife relationships and related decision-support tools, and (e) impacts of potential future climate change on forest management. Dr. Duinker recently presented two papers that will appear soon in conference proceedings: "Wildlife in forest management: from constraint to objective", to appear in Forest Investment: A Critical Look, in preparation at the Great Lakes Forestry Centre, Sault Ste. Marie; and "Sitespecific silviculture: what's the appropriate context?", to appear in Tools for Site-specific Silviculture in Northwestern Ontario, in preparation at the Northwestern Ontario Forest Technology Development Unit, Ministry of Natural Resources, Thunder Bay.

\section{C.A. Benson}

\section{Toronto}

\section{Daniel Kneeshaw CIF Gold Medal Winner}
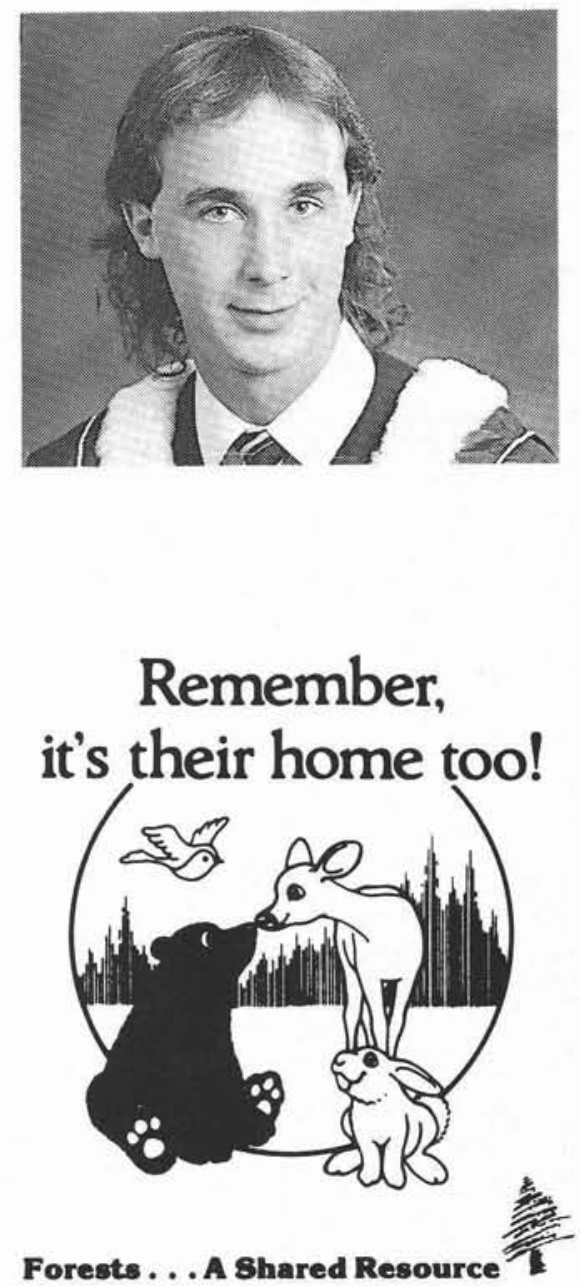
Dan Kneeshaw entered the University of Toronto's Faculty of Forestry in the 1985-86 academic year after receiving his Ontario Secondary School Honour Graduation Diploma from Markham District High School. At graduation he received the Ontario Scholarship award.

In each of the four years at University, he was on the Dean's Honour List. During this time, he played on six of the Faculty's intramural sports teams as well as coaching and refereeing in three of these sports. While at the Faculty. Dan was a member of the Faculty's Employment Committee, co-editor for the Forestry yearbook and a member of the Forester's Club (the undergraduate student governing body), of which he was VicePresident in his final year

Recently he has been travelling in western Canada on his way to Asia.

\section{British Columbia}

\section{Faculty News}

Twenty-six BS.F and four B.Sc. degrees were awarded to the following students. The title of graduate essays or theses were as follows:

\section{Students' Names and Titles of Graduating Essays}

BYSOUTH, Doug B. - Factors affecting high elevation regeneration success in the ESSF biogeoclimatic zone.

CLARK, Larry W. - A comparison of costs and productivities of grapple yarding with and without a mobile backspar.

DAVIS, Mike - An economic study of a decadent mid-coast stand.

DILLABAUGH, Les - The implementation of the allowable cut effect in British Columbia.

EAKET, Bruce E. - Database management: A detailed literature review.

FOSTER, Susan M. - An afforestation strategy for India's fuelwood-dependent people.

FRIER, David J. - The effect of various site preparation methods on the early growth of Engelmann spruce.

FRY, Kimberley - The fuelwood crisis in India.

HALL, Randal G. - Precipitation intensity duration frequency curves for Jamieson creek and Elbow creek watersheds in the Seymour Basin.

LEUNG, Walter - Effects of the Canadian and US Free Trade Agreement on the BC softwood lumber industry.

LUNDE, Douglas - A review of the firelog industry in B.C.
MCKINNON, Grant - Central tire inflation systems and their logging applications.

MOSHENKO, Darcy W. - British Columbia highway logging truck analysis.

NIELSEN, Mike - The effects of timber harvesting on salmonids in southwestern British Columbia.

ORAN, Robert J. - A brief review of the stagnating Sitka spruce plantations on northern Vancouver Island with emphasis on salal fineroot biomass.

ROESSLER, Craig M. - The Brazilian Amazon and its relationship with man.

SINCLAIR, Alisa - The use of precast concrete in the construction of permanent logging bridges.

AINSWORTH, D. Michael - Opportunities for standard lumber products in the glulam industry.

CHIU, Edwin - The need to sort before high temperature drying of Hem-Fir.

VON SCHILLING, Bodo - Soil compaction and lodgepole pine growth - A historical examination of landings in the Prince George region.

ALEMAN, Jan K. - The effects of comparative value timber pricing on silviculture.

AMIES, Brian - Management plan for private woodlot F52-45-25.

ANDREWS, Peter S. - Initial growth comparison and site index estimation of lodgepole pine and white spruce regeneration on ecosystem associations within the BWBS CL and $D$ subzones of northeastern British Columbia.

HENRY, Lawrence E. - Height vs. age curves as an aid to species selection in the eastern Kamloops forest region.

HROMADNIK, Kevin T. - An analysis of seedling survival for six different stock types in the Cariboo forest region.

KATUSKI, Jeffrey - Relationships between fire weather index system codes and indexes and fuel consumption during slashburns in the Sub-Boreal spruce zone of central British Columbia.

MACIVER, D. lan - An study of root development of two stock types of Douglas-fir.

MACKENZIE, Kenneth J. - The interactions between Vacinium alaskaense and Abies amabilis in the upper CWHB2 variant.

MINDEK, Jack L. - Influence of climatic factors on a chort effect in early horn growth of dall's sheep of the Southern Yukon.

MORRIS, Rhonda L. - The effects of the new forest policy on silviculture practices applied to the crown lands of British Columbia.
ONEIL, Elaine - Bald eagle nesting relative to forestry operations on MacMillan Bloedel forest lands.

PEMBERTON, Christopher - Salal eradication and hemlock fertilization at Port McNeill, British Columbia: Third-year height response.

REGEHR, Sylvia J. - Management implications of precommercial thinning in Interior, wet-belt, Douglas-fir.

STUMP, Werner K. - Noble fir provenance study on northern Vancouver Island.

\section{CIF Gold Medal}

The 1989 Canadian Institute of Forestry Medal at the University of British Columbia was awarded to Werner K. Stump. Werner grew up in Malakwa, a small forestry town in the interior of B.C. He graduated at the top of his high school class and then attended Okanagan College for one year in a science program.

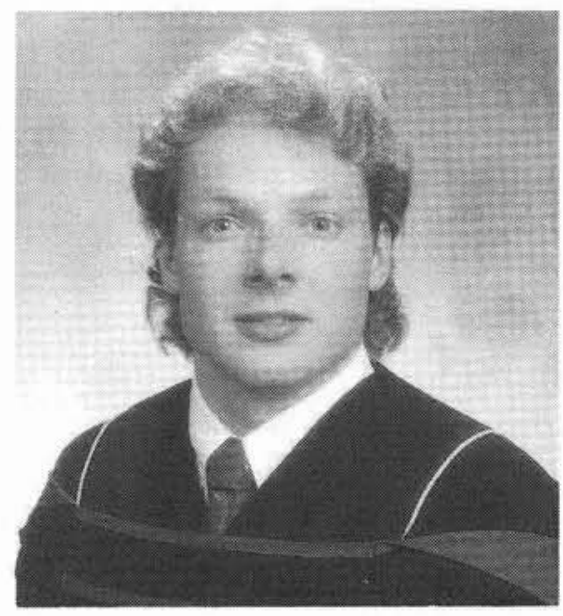

In 1985 Stump enrolled in the Forest Resources Management program at UBC, and concentrated on foiest industry economics and management accounting. Werner won numerous scholarships during his undergraduate studies. During the summers he worked both in the interior and on the coast of the province in forest engineering and production.

Werner is now employed as a Junior Business Analyst in Weldwood of Canada's corporate planning department. We wish him a successful and rewarding career in his chosen profession.

\section{New Appointments in Harvesting and Wood Science}

FANNIN, Dr. R. Jonathon - Assistant Professor - Harvesting Transportation FEE Appointment. B.Sc. Queens University of Belfast, D.Phil. Oxford University.

Research interests concern the application, design and use of geosynthetics in problems of slope stabilization, bearing capacity on soft soils and trafficability of 
unpaved roads. Research experience is based in field studies of instrumented structures and in laboratory testing.

MCNEEL, Dr. Joseph - Assistant Professor - Harvesting Systems FEE Appointment. B.S.F. West Virginia University, M.S. Virginia Tech., Ph.D. Virginia Tech.

Research interests include economic analysis of timber transport systems, economic and production analysis of prototype fellerbuncher sawheads in Southern conditions, and the impact of machine design in shear felling. Other research interests include systems analysis through simulation and economic analysis of machine/system interactions.

\section{Forestry Canada Continues FEPA Support}

The Honourable Frank Oberle, Minister of State (Forestry) announced on June 12 that Forestry Canada would contribute $\$ 250000$ for the fiscal year $1989 / 90$ for the support of the Forest Economics and Policy Analysis Unit at the University of British Columbia These funds continue an initiative started in 1984 when the federal government contributed $\$ 2$ million towards the establishment of a Canadian centre of excellence in forest economics. FEPA is responsible for investigating economic and policy issues related to Canada'a forest resource industry and the international forest products market.

\section{New Brunswick}

\section{Wood Science and Technology Centre Opened}

The University of New Brunswick's Wood Science and Technology Centre (WSTC) was officially opened on Friday, May 12, in conjunction with National Forest Week. Participating in the opening ceremony were the Hon. Frank Oberle, Minister of State (Forestry); the Hon. Morris Green, N.B. Minister of Natural Resources and Energy: Bob Neill, chairman of WSTC's board of management; and Ian Smith, director of WSTC.

The UNB Wood Science and Technology Centre was established with the assistance of $\$ 500000$ in grants from the federal and provincial governments. Its mandate is threefold: to develop and transfer technology. to solve industrial problems, and to promote technological and commercial development related to wood science within the Atlantic provinces. WSTC is housed within the Tweeddale Centre for Industrial Forest Research at the Hugh John Flemming Forestry Centre in Fredericton.

\section{Student Prize Winners}

At UNB's 160th Encaenia in May, 32 students graduated from the Bachelor of Science in Forestry program and eight received Bachelor of Science in Forest Engineering degrees.

The following students were awarded prizes:

Lieutenant-Governor's Silver Medal Christopher Heinrich, Hudson, Que.

Canadian Institute of Forestry Merit Award - Edward Wilson, Edinburgh, Scotland.

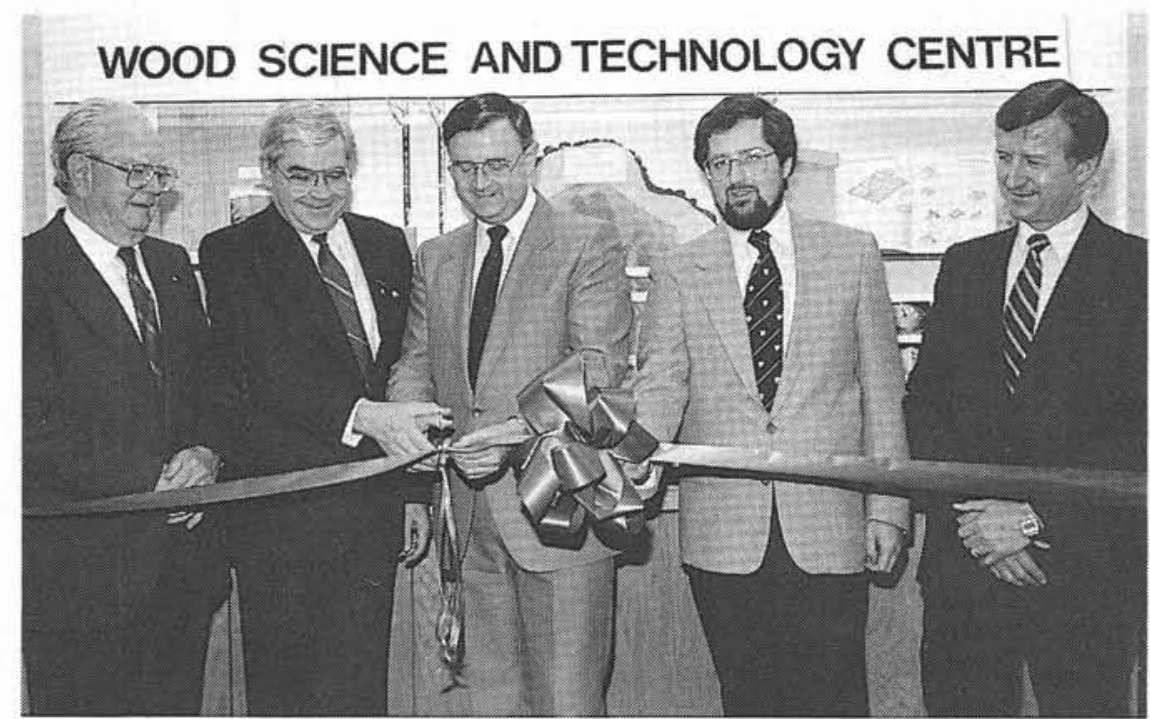

Shown during the ribbon cutting ceremony for UNB's Wood Science and Technology Centre are, left to right, the Hon. Morris Green, N.B. minister of natural resources and energy; the Hon. Frank Oberle, minister of state (forestry), Dr. Ian Smith, WSTC director; Dr. Bob Neill, chairman of WSTC's board of management; and Dr. Reg Tweeddale. (Photo credit: Robert Wilson).

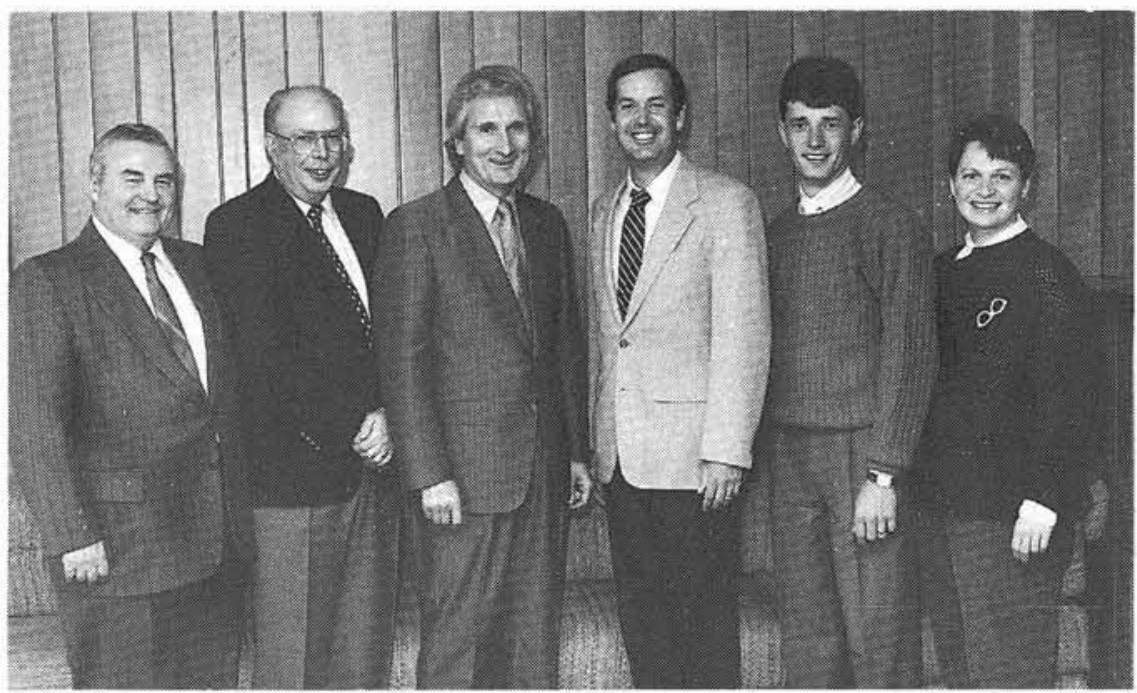

\section{Forestry Faculties Visit}

To establish and strengthen research ties with their peers, the Faculty of Forestry at the University of New Brunswick hosted faculty members from three eastern forestry universities last May. Pictured, left to right, are: Dr. Alex Dickson, coordinator of continuing education in forestry, UNB; Dr. Gordon Baskerville, dean of forestry, UNB; Dr. James Downey, president of UNB; Dr. Chris Murdoch, University of Maine at Orono; Prof. Edgar Robichaud, University of Moncton at Edmundston; and Prof. Johanne Morasse, Laval University. (Photo credit: S.L. Howland).

G.D. Estey Memorial Prize - Roger Prince, New Carlisle, Que.

Canadian Forestry Equipment Prize - David Tulk, Corner Brook, Nfld.

Videto-Hadley Memorial Prize - Bruce Matson, Thornhill, Ont.

Faculty of Forestry Senior Project Award John Deal, Lunenburg, N.S.

Lucien J. Forcier Prize in Silviculture Christopher Heinrich, Hudson, Que.

Schlich Memorial Prize - Peter Jofriet, Guelph, Ont.

\section{CIF Gold Medal Recipient}

Edward R. Wilson of Edinburgh, Scotland, is the University of New Brunswick's recipient of the CIF Gold Medal for 1989.

$\mathrm{Mr}$. Wilson obtained his bachelor's degree in forestry at UNB's 160th Encaenia in May. During his senior year, he successfully satisfied the award's two main criteriaparticipation in faculty activities and high academic achievement. His extra-curricular activities included organizing a study tour to Sweden for 19 members of the UNB Forestry 


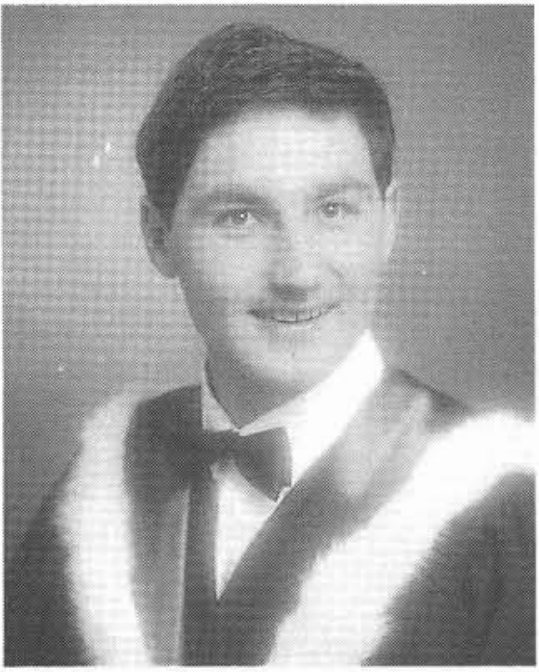

Photo caption D: Edward Wilson. (photo credit: The Little Studio).

Association, being an undergraduate lab instructor, proctor of UNB's McLeod House residence, and library assistant for the UNB Science and Forestry Library. As an undergraduate, Mr. Wilson received eight scholarships for academic performance, achieved a Dean's List standing three times and attained a cumulative grade point average of 3.7. He has recently been awarded a scholarship from the National Sciences and Engineering Research Council (NSERC) to continue his studies at the graduate level.

\section{Schlich Memorial Prize}

UNB graduate Peter J. Jofriet of Guelph Ont., is this year's receipient of the Schlich Memorial Prize.

The prize, which consists of a book on forestry, rotates annually among the seven Canadian forestry universities. It is named in honour of Sir William Schlich (1840-1925 who was the inspector general of forests for

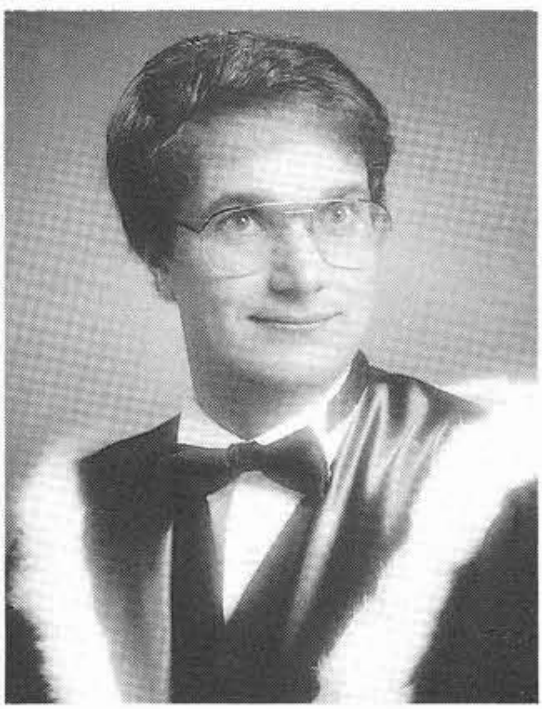

Photo caption E: Peter Jofriet. (Photo credit: The Little Studio)

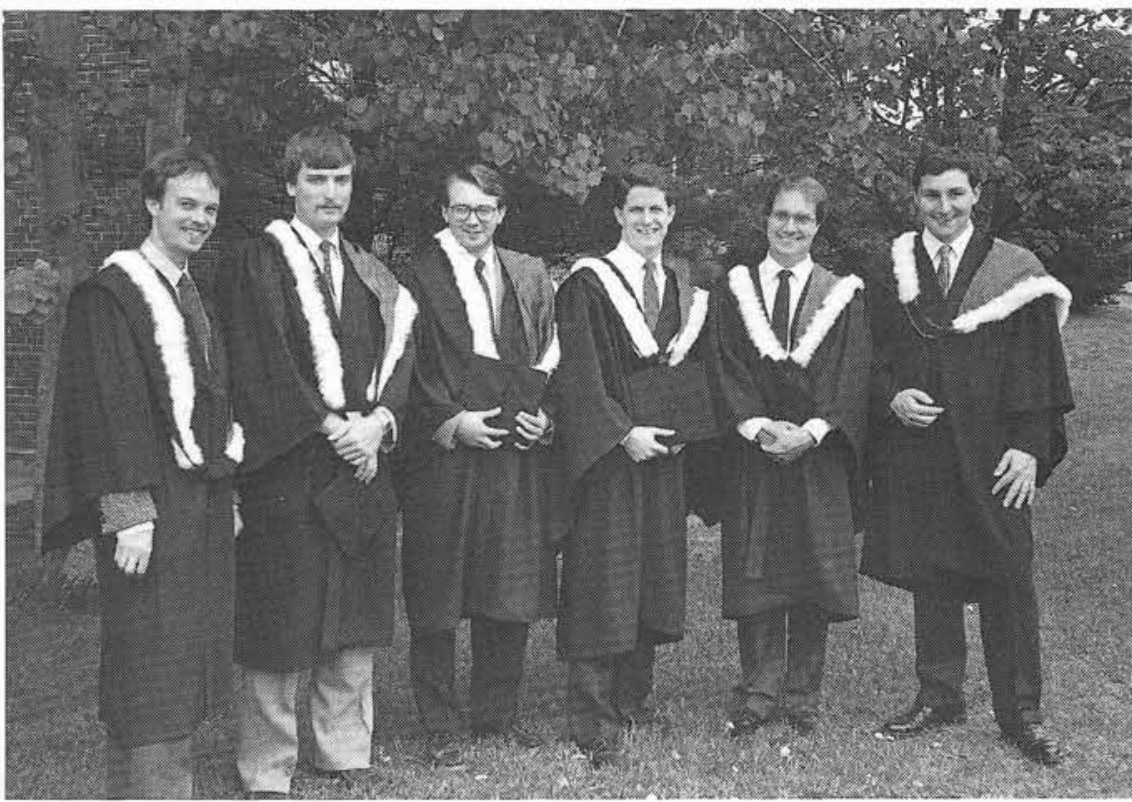

Seven faculty of forestry graduates received prizes at UNB's 160 th Encaenia. Pictured left to right are Christopher Heinrich, Roger Prince, John Deal, Bruce Matson, Peter Jofriet and Edward Wilson. Absent: David Tulk. (Photo credit: A. Dickson).

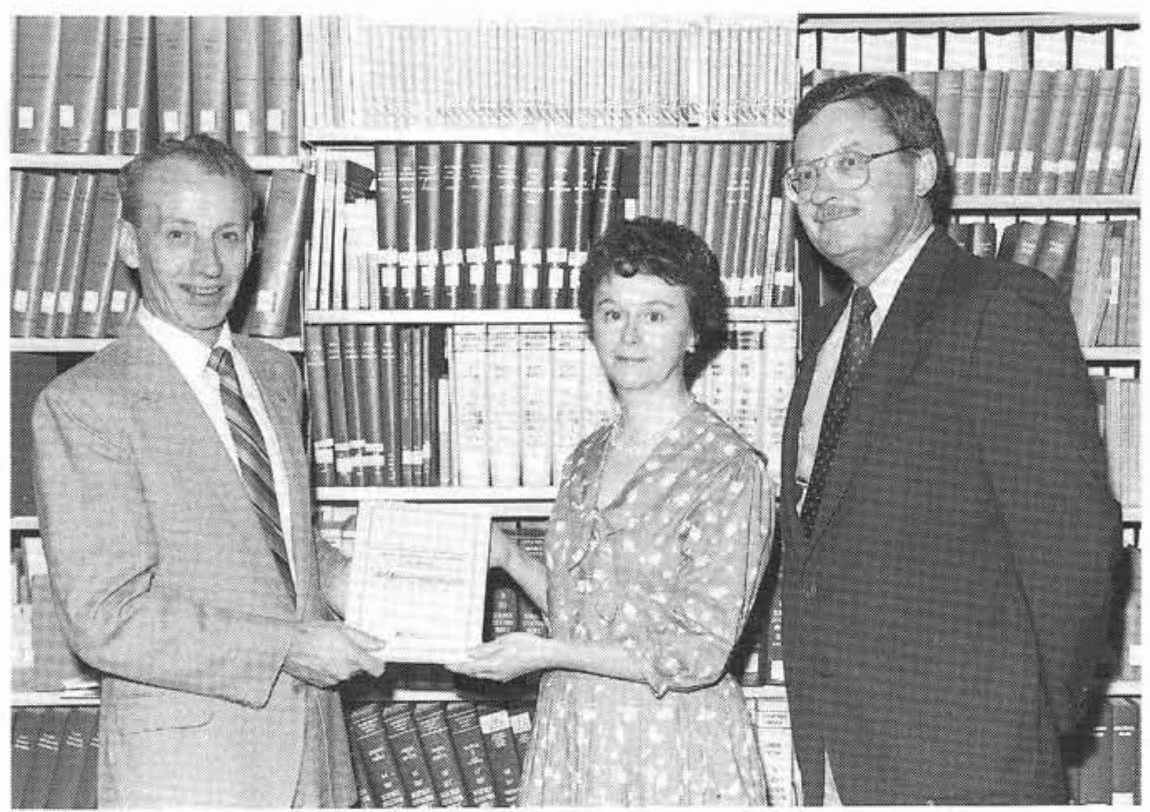

\section{Book Donated}

Fraser Inc. of Edmundston, N.B., is giving the acquisition department at the University of New Brunswick's Science and Forestry Library a helping hand. Mr. Niall O'Briain (left), president of Fraser Inc., presents the Aktrin research report on The Pulp, Paper and Allied Industries in Canada to librarian Janet McNeil and Dr. Tim Easley, chairman of the department of forest resources. The publication is valued at over $\$ 1800$. (Photo credit: W.L. Staples).

the government of India, a forestry professor at Oxford University and the author of several well-known technical forestry books.

Mr. Jofriet was awarded the prize on the basis of his outstanding academic achievement in pursuit of his bachelor's degree in forest engineering. He graduated first in his class last May with a cumulative grade point average of 3.9. As an undergraduate, $\mathrm{Mr}$. Jofriet received numerous scholarships. $\mathrm{He}$ has also been awarded a National Sciences and Engineering Research Council (NSERC) scholarship to continue his studies at the graduate level.

\section{Papers Published}

Hartley, I. and M.H. Schneider. 1989. "Modelling direct current resistivity of wood polymer composites." Wood and Fiber Science 21(3) 
Schneider, M.H. et al. 1989. "Toughness of impregnated sugar maple at two moisture contents." Forest Products Journal 39(6): 11-14.

\section{Faculty Briefs}

Dr. M.S. Jamnick presented a paper entitled "Multiple ownership and competing values in commercial forest lands" at a conference on Applying Science to Environmental Policy in Canada and the United States in Big Sky, Montana, June 3-6.

Prof. E.J. Rickards and Dr. C.-H. Meng gave a workshop on production data collection to the Newfoundland Department of Forestry in St. John's on June 15-16.

During June, Prof. Rickards also had a paper presented to the American Society of Agricultural Engineers, entitled "Forestry equipment maintenance: An analysis of component parts cost." He participated in a National Research Council workshop on education and ergonomics in Ottawa. And, at the end of the month, he travelled to As, Norway. to chair a work study on Nomenclature/Terminology in Forestry for Working Group S3.04.02 of the International Union of Forestry Research Organizations (IUFRO). The working group is trying to develop an international set of terminology to present at the IUFRO World Congress in 1991.

Prof. G.A. Jordan co-instructed a microcomputing workshop for gifted high school students June 26-29 on the UNB campus. He also presented a paper at the Urban and Regional Information Systems Association Conference in Boston, Mass. Aug. 6-10. It is entitled "Six years before the mark: A chronicle of GIS experience."

Prof. Jordan has been elected to a threeyear term as a councillor for the Maritime Section of the Canadian Institute of Forestry.

Dr. A.H. Boer presented a poster session paper entitled "LORAM-C as a navigation aid in aerial surveys" at the North American Moose Conference in St. John's, Nfld., July 8-14. He also visited the Adirondack Ecological Center in Newcomb, N.Y. on Aug. 10 to give an invited lecture on "Exploring the role of hunting in New Brunswick moose populations."

Dr. H.H. Krause began a one-year term as president of the Canadian Society of Soil Science on July 11 th.

Dr. I. Smith was at Kasetsart University in Bangkok, July 13 and 14 , to present two papers on establishing a wood science and technology institute. He gave a technical forum presentation at the 43rd Annual Meeting of the Forest Products Research Society in Reno, June 25-28. And he presented two papers at the Pacific Timber Engineering Conference in Auckland New Zealand, Aug. 28-31.

Dr. M.R. Roberts presented two papers at the Ecological Society of America meeting in Toronto, Ont., Aug. 6-10. They are entitled "Response of understory trees to canopy gaps in a 150-year-old northern hardwood forest," co-authored with C.L. Jolls and M.E. Banfield, and "Interactions of soil organic matter, soil fertility and herbaceous vegetation in successiorial forests of northern lower Michigan," co-authored with F.S. Gilliam.

Dr. G.R. Powell, chairman of the Tree Seed
Working Group of the Canadian Tree Improvement Association (CTIA), organized two workshops in conjunction with the association's 22nd Biennial Meeting in Edmonton, Alta, Aug. 14-18. The workshops were entitled Cone and Seed Crop Monitoring and Cone Induction: Response to Practise. He presented a paper at the former: "What is there to monitor, and when and where? An overview of cone development for spruce, larch, and pine."

Dr. E.K. Morgenstern also attended the CTIA meeting at the University of Alberta and gave an invited paper. $\mathrm{He}$ is a member of the IUFRO working party on Northern Forest Silviculture and Management which held a symposium on the Silvics and Ecology of Boreal Spruces, in St. John's, Nfld., Aug. 12-17. Dr. Morgenstern was the senior author of an invited paper which was presented at the symposium.

\section{Upcoming Course}

Forest-Land Appraisal, January 14-19, 1990

This course covers the basic theory of real estate appraisal as it applies to forest-land properties. It is designed for those forestry professionals in Canada and the U.S. who require an understanding of the principles of real estate appraisal and how they affect forest-land valuation and investment decisions. Registration deadline: Oct. 6. Location: the Hugh John Flemming Forestry Centre in Fredericton, N.B.

For more information contact $\mathrm{Dr}$. Alex Dickson, coordinator of continuing education in forestry, or Ardith Armstrong at (506) 453-4501.

\section{Forestry Focus}

The Summer 1989 issue of the UNB Forestry Focus (Vol. 14, No. 3 ) is now available. It contains an annotated list of graduate theses and selected undergraduate reports produced within the faculty of forestry during the 1988-89 academic year. These theses and reports may be borrowed. To obtain this issue of the Focus, contact: Coordinator, Continuing Education in Forestry, University of New Brunswick, Bag Service \#44555, Fredericton, N.B. E3B 2C1, (506) 453-4501.

Sandra Howland

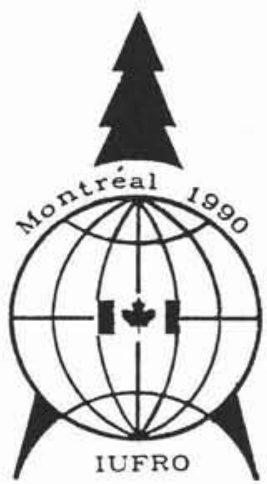

\section{CONGRÈS MONDIAL DE L'IUFRO}

5-11 août, 1990

Le "Document d'information sur le
Congrès" est maintenant disponible
comme le Volume 63 de IUFRO NEWS.

IUFRO NEWS est distribué par le secrétariat de l'Union Internationale des Instituts de Recherches Forestières situé à Vienne en Autriche. Vous pouvez aussi l'obtenir en écrivant à:

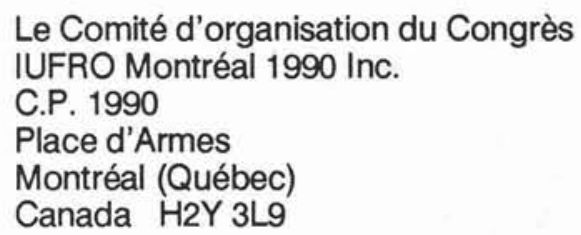

